\title{
TREE OF LIFE: TEACHERS' REFLECTION ON THEIR TEACHING CAREER
}

\author{
Mai Ngoc Khoi* \\ Faculty of English Language Teacher Education, VNU University of Languages \\ and International Studies, Pham Van Dong, Cau Giay, Hanoi, Vietnam
}

Received 06 August 2018

Revised 27 September 2018; Accepted 28 September 2018

\begin{abstract}
This article discusses the use of narrative inquiry in educational research and emphasizes the importance of giving teachers opportunities to self-reflect and share their insights with other colleagues. It presents the narratives collected after the first stage, data collection, of an on-going narrative project using the tool 'Tree of life' to facilitate teachers' self-reflection on their teaching career as a professional development activity. This activity provides a large amount of teacher-generated data while allowing teachers to reflect on some critical incidents in their career and gain self-knowledge which is as crucial to good teaching as knowing students and the subject they teach. By telling their stories, teachers can come to know themselves better and really appreciate how much they have accomplished and grown during their career, thereby making appropriate and meaningful plan for future professional development.
\end{abstract}

Keywords: narrative inquiry, self-reflection, tree of life, teacher professional develoment

\section{Introduction}

Professional development is an essential part of all teachers' lives. It is a process of "continual intellectual, experiential, and attitudinal growth" (Lange, 1990, p. 250). This process happens in both formal and informal settings across different contexts including both the schools where teachers work and the community where they live. This lifelong learning commitment starts during their study at their teacher-training institutions and continues long after their graduation.

There are two approaches to teacher professional development. Traditionally, teacher professional growth is presumed to happen through workshops conducted by outside experts. This top-down approach to

* Tel.: 84-987349684

Email: khoi.maingoc@gmail.com professional development assumes that the transmission of knowledge in workshops can change classroom-teaching behaviours. In reality, workshop sessions of this nature have little actual or only short-term effects on classroom teaching (Farrell, 2007). The recent literature supports the view that teachers rather than the outside experts are the "legitimate knowers, producers of legitimate knowledge, and as capable of constructing and sustaining their own professional practice over time" (Johnson \& Golombek, 2002, p. $3)$. This bottom-up approach to professional development assumes that professional development happens as teachers articulate their inner world of choices as responding to the outer world, their teaching context (Mann, 2005). Teachers are believed to be capable of creating difference as they explore the nature of their own decision-making and classroom practices via reflective practice. 
Earlier, Wallace (1991) identified three major models of teacher professional development:

- An apprenticeship model in which less experienced teachers learn from those with more experience;

- An applied science or theory-to-practice model in which teachers learn from research and experts then apply this knowledge in their own contexts;

- A reflective approach in which teachers critically analyse, reflect on, and adapt their own practice.

All three models require teachers to be reflective and routinely question their own teaching practice and beliefs about teaching and learning while being sensitive to the complex cultural contexts where they work (Murray, 2010; Wallace, 1991). Critical reflection, therefore, plays a key role in effective professional development for teachers. Farrell (2007, p. 176) summarises that reflective teachers can develop:

- a deeper understanding of teaching;

- an evaluation of what stage they are at in their professional growth;

- more skills in self-reflection and critical thinking;

- more complex and clearer schema about teaching;

- a more coherent personal approach to classroom teaching;

- more elaborate pedagogical reasoning skills;

- more informed decision-making skills;

- themselves as more proactive and confident teachers.

According to Farrell (2007), there are three main types of reflective practice, namely reflection-in-action, reflection-on-action, and reflection-for-action. The difference between these three types lies in the time of reflection and its purpose. Reflectionin-action happens during the event, such as classroom teaching. Reflection-on-action occurs after the event, and reflection-foraction takes place when teachers think about future actions. In addition, there are two main approaches to reflective practice. The first one emphasises reflection only on classroom actions while the other involves the broader historical, sociopolitical and moral context of schooling. Only through the latter, known as critical reflection, can teachers become agents of change (Farrell, 2007).

As the bottom-up approach to teacher professional development becomes more and more popular, the concept of professional development has expanded to reflect interactions between teachers, their teaching, and their contexts. Hardy (2012) understood teacher professional development as a situated, multi-faceted concept. $\mathrm{He}$ approached professional development as policy, research, and as a part of teachers' work. He defined teacher professional development as a socio-political practice influenced by teachers' working and living contexts and the individuals or groups who are engaged in, support and create it. He argued that it is essential to recognise the complicated nature of the concept and the interaction, sometimes conflictual, between the factors and people involved in order to offer effective professional development for teachers.

In short, the modern view on teacher professional development has shifted to a long-term approach that facilitates teachers' development via reflective practice and collaborative learning while being sensitive to the contexts where teachers live and work. One way of doing this is to embrace narrative inquiry as a qualitative research methodology 
allowing an investigation into the ways in which human experience the world as revealed through their stories.

\section{What is narrative inquiry?}

Narrative inquiry has a relatively long history in general teacher education research and is a fast growing interest in the field of language teacher education (Barkhuizen, 2008). As teachers are no longer viewed just as subjects of study but rather as knowing professionals or agents of change (Johnson \& Golombek, 2002), their narratives of experiences have become the subject of research. The increased emphasis on teachers' reflective practice, teachers' knowledge (i.e., what they know, how they think, how they develop professionally, and how they make decisions in the classroom), and the increasing importance of teachers' voices talking about their experiences have all contributed to the emergence of narrative inquiry and its popularity over the last few decades (Cortazzi, 1993). As narratives can provide a way into teachers' beliefs and experiences, narrative inquiry can help understand those beliefs and experiences.

Connelly and Clandinin (e.g., Connelly \& Clandinin, 1986, 1999, 2006; Clandinin \& Connelly, 2000) are important figures adapting narrative inquiry for educational purposes. They argued that through telling and retelling, living and reliving teachers' own stories, teachers' lived experiences, including their knowledge and practices, could be interpreted and understood narratively.

Clandinin and Connelly (2000) trace the core of narrative inquiry to Dewey's (1938, 1991) theory of experience. Dewey argued that human beings learnt from reflecting on experience, confronting the unknown, making sense of it, and taking action. For him, experience is both personal and social because people are individuals but they are always in relations, or in other words, always in a social context. Studying one individual's experience, for example of language learning, would therefore involve more than that individual's learning but also require understanding of that experience in the individual's context, for example, learning with other people, with a teacher, in a classroom, in a community, and so on. Dewey also argued that experience was continuous as one experience led to another. Any individual's learning experience always has a history and that history is everchanging as new events unfold. Narrative inquiry embraces these two characteristics of experience, namely interaction and continuity, and is conducive to documenting the changing conditions of lives and the impact these new conditions can have over time on all aspects of an individual's life, including language learning. It recognises that people make sense of their experiences according to narratives that are constantly being restructured in the light of new events, and also acknowledges that these narratives are shaped by lifelong personal and community narratives (Bell, 2002).

One challenge that all narrative inquirers face is how to best present their work. Because narrative inquiry goes beyond simply telling stories to an analytical examination of the underlying insights and assumptions that the story illustrates (Bell, 2002), and also because of the limited space given in journal publication, the stories of participants are often not reported with their richness of detail and experience. One common practice is for the researchers to retell part of the stories or quote some sentences from the stories. This however raises the problem of ownership of the stories while taking away the chances for the narratives to be reanalysed by readers and 
other researchers from a different perspective. I therefore decide to publish the study in two different articles with the first one presenting the narratives generated by the participants and the follow-up article providing my interpretation of the data. Other researchers, therefore, are also invited to interpret the data from their own perspectives to contribute to a complex understanding of our participants.

\section{3. 'Tree of life': A tool for self-reflection}

The research reported in this paper uses the self-reflective tool 'Tree of life' (Merryfield, 1993) which allows teachers to begin their self-reflections by telling their story: where they come from, where they are now, and where they want to achieve, and how to get there. By retelling and outlining their personal history and teaching careers, teachers can better understand themselves along with exploring other aspects of their work. This practice of self-reflection is important, as research has shown that when self-reflecting, teachers can:

- recall previous experiences for selfdiscovery;

- become more aware of who they are as teachers;

- become more aware of how they got to where they are at present;

- become more aware of what they have accomplished over their career;

- decide what is important for them personally and professionally;

- become more aware of their thoughts, actions and feeling;

- decide where they may want to go in the future both personally and professionally;

- gain keen insight into themselves and their practice;
- share with other teachers a strong sense of personal identity that infuses their work.

(Farrell, 2007, p. 15)

'Tree of life' is a popular metaphor found in many fields such as biology, philosophy, mythology, and religion. It focuses on the lives of individuals while recognizing that the individual is the expert of their own lives. Retelling their personal stories can identify significance in them, making it possible for individuals to actively take steps to preferred ways of being in the world (Bruner, 1986; White \& Epston, 1990).

The main elements of the tree were adapted to incorporate the narrative approaches: the roots, trunk, and the limbs, which represent the early influences, later influences, and the most recent influences respectively. Over the years, tree of life was further developed to have more elements including the leaves, fruits, and the bugs (Ncube, 2006). When thinking of the roots, teachers will focus on their origins and family history. The trunk of the tree is a prompt for significant events that have shaped their lives: these are either positive events or events that are difficult or evoke a painful memory. The leaves of the tree represent important people or significant relationships in ones' life, for example parents and favourite teachers. The branches of the tree elicit participants' thoughts and ideas about the direction they would like to go in life and the important actions which play an important role in making them teachers. The fruits stand for the achievements which participants have accomplished or the things which they are proud of. Finally, the bugs of the tree represent the negative factors, the problems and challenges teachers are facing in their day-to-day teaching and lives. By labelling these various parts of the tree, reflective practitioners can discover or 
rediscover aspects of themselves as formed by past events, and can actively cultivate their trees to reflect the kind of person they want to become and the goals they aim to achieve.

The research presented in this paper is an on-going project which is divided into two stages. In the first stage, seven in-service teachers reflect on their life history and teaching career, retell them using the metaphor 'Tree of life'. The participants are university lecturers at an institution in the Northern part of Vietnam. Of the seven teachers, Mark is the youngest who graduated from a teacher training university last year and recently has enrolled in a postgraduate program. Sharika and Kate both have about six years of teaching experience and have earned their Master degree after studying abroad in Australia. Susan earned her Master some years ago, and in her own words, still "navigating the field" to find a suitable career path. Cathie earned her Master recently while Mollie and Liam were recently awarded their PhDs. These participants were chosen because they are willing to participate in the study, which is essential in conducting narrative inquiry research. In addition, the participants are currently at different stages of professional development which allows diverse narratives to emerge. Mutual trust between participants and the researcher also plays a crucial role as it allows candid reflection. The reflective activity with "Tree of life" provides participants opportunities to reconsider their identity, based on the rationale that our self-identities are shaped by our own accounts of our lives and the stories we tell about ourselves (White \& Epston, 1990). This narrative practice also allows individuals to identify their strengths and find ways to achieve their goals. The second stage of the study draws on the concepts of collective narrative practice, during which participants share their tree of life, make bonds with each other, identify shared problems in the context where they teach and live, thereby addressing social issues and building a community of practice which allows safe and meaningful professional development activities to take place.

This paper, as an on-going report, focuses on the first stage of the project, presenting the tree of life narratives of eight teachers. They are all motivated and accomplished teachers although currently at different stages of their career and have very different experiences. As I refrain myself from summarising and reducing their life experiences into a few sentences, the readers can read through their stories retold in their own words in the section below. All the narratives were written by the participants themselves in English. The name of the teachers, however, have been changed to maintain anonymity. Regardless, I suppose many readers would see themselves in these stories or would connect them with someone they know of. This is because human experience is unique but also a shared experience.

\section{Teachers' narratives}

\subsection{Participant 1: Mark}

Root: I come from a typical Vietnamese family, with my parents wanting me to study well and have a stable job in the future. Since my early childhood, I have had an introverted personality, preferring to read books and have long discussions about knowledge and ideas with other people. I like learning new things and sharing what I know with other people who might be interested. Perhaps most important of all, I like being able to help others.

Trunk: I first became interested in learning English in my eighth grade, mostly because I wanted to understand English songs, movies, TV programs and books in their original 
language. I was first inspired to learn English seriously in my eleventh grade by my high school English teacher, who established a great rapport with her students and could make each English lesson relaxing and interesting. I started helping some of my classmates to improve their English in my twelfth grade, which gave me my first impression of teaching. During my preparation for the university entrance exam, I was inspired to become a teacher by a great English teacher at a local cram school, who always prepared very thorough lessons and was always willing to answer each student's questions. I wanted to be like him and decided to pursue a career in English language teaching.

Branch: During my years in pre-service education, I was both a student of many good teachers and a part-time English tutor to many high school and college students. These two simultaneous roles allowed me to apply what I had learned about teaching to practice and further consolidated my passion for teaching. I had a few months working in the Teaching Practicum at a college in Hanoi, which helped me accumulated real experience in teaching, especially in my classroom management and lesson planning. After graduating, I applied for a teaching position at my university and was accepted. During my time here, I received frequent training sessions from experienced teachers in the faculty (e.g. frequent INSET training, Mentoring program, etc.) These opportunities allowed me to polish my skills further and become a better teacher. I have recently started my Masters' program. I am beginning to learn more about researching and how to apply theoretical knowledge in the practice of teaching. The more I learn, the more I feel interested in my work and my study.

TPD Plan: By examining my own journey to become a teacher, I can see which aspects of my job I am still weak at, as well as which factors in my life and my personality I can use as motivation to help me become better. For example, I believe I have not accumulated enough experience with teaching, and I plan to fix this by using mentoring and classroom observation and by conducting research to help me develop my teaching competence. I know I am only in the early stage of my career as a teacher, but I believe that my interest in learning foreign languages and my enthusiasm for sharing what I know with others might be what I can use to motivate myself to become a better teacher.

\subsection{Participant 2: Shakira}

Root: I was born in an average Vietnamese family with my father being a mechanics and mom being a house wife. However, as my deceased grandfather always wanted his daughters and grand-daughters to pursue any paths with a 'foreign' element, so my parents wanted me to become an English teacher. I was too young to understand any of their wish, but then one day, one friend of the family came back from America and gave us a Walt Disney movie video. The movie was Beauty and the Beast. Back then, there was neither subtitle nor dubbing; I could barely understand what they said but I was so interested in the plot, with the music, with the voicing. I watched it over and over again, until I could even 'shadow' the character in the exact manner they were acting. And on top of that came the beautiful soundtrack 'Tale as old as time'. Along with the movie were the era of Michael Jackson, Bryan Adams and many other rock bands. I listened and sang along without knowing what I was really singing. I had no idea that I fell in love with English, but I think I did.

Trunk: My school years were very simple and oriented by parents. Except for Primary School, I was in English specialized class in 
both secondary and high school. Still, I didn't have a vision of what my future job would be. Even during my four years in University of Languages and International Studies, I didn't give a thought about teaching job. My parttime job back then was translating movies and TV series for Vietnam National Television. I was like I would never have a teaching job. A few months after my graduation were rough. I worked at ULIS for two months before embarking on a youth exchange program for another two months. During the program, I travelled and met so many interesting youths of all ASEAN countries, which made me feel like teaching was definitely not my thing. Upon my return, I worked for the school for another year with the thought that I would leave once the contract finished. But then, that one year changed me even more, and now I would say I love my teaching job. Even when I'm not teaching English, I would love to teach something else.

Branch: My first few years at school were, I would say, ok. I liked my students; they were only 4 years younger than I was so we got along quite well in class. I was assigned with a mentor but to be honest, that was a disappointment because he never showed up in my class. However, other senior colleagues were really helpful in giving advice about teaching, adopting materials, and managing my class. Also, many of my classmates were in the same division with me, so in a way, I found a sense of belonging. In 2013, I commenced my Master degree in Educational Leadership in Australia. I was enlightened with so much new knowledge about leadership, organizational behavior, human resource management that every time I reflected on what had happened, they all made sense. I also learned something important: I don't need to push myself to attain a high position to make a change, I can make changes in everything I do to my students and colleagues. Coming back to Vietnam, working in the same division as before, I initiated some new ideas to the materials and received good feedback, which made me want to contribute more. Also, I was given chance to become a mentor. Working with new teachers inspires me in an absolutely different way than with students because they are grown-ups, they are proactive in learning but at the same time a bit lost in this new career. Working with my mentees, listening to their joys and worries, knowing that they are making progress, I find my job more meaningful. I must say I see myself a bit clearer everyday thanks to my mentees. So, I may be an introvert, but still love working with people. That's why I guess I will pursue teaching my whole life.

\subsection{Participant 3: Kate}

Root: There is no one who works as a teacher in my immediate family. However, in my father's side, all of my grandmother's nephews and nieces are teachers of all kinds of subjects ranging from primary to high school level. So, somehow, I could say it runs in the blood. I remember I seemed to get the approval and support of "the whole universe" when choosing teaching career. Most of my close friends, despite my objection, regard me as a kind, smart and humorous person. I like readings book, watching documentary films, learning new things and gain new experiences. Within my capacity, I enjoy helping others.

Trunk: My parents were very different from those of my friends in the way that they did not force me to learn days and nights to get recognitions and prizes. I spent my time equally on both learning and playing. Funnily enough, I always studied well at school and got almost all of those things, I mean recognitions and prizes, which never stopped surprising my parents. I truly enjoy studying, 
just as my favorite hobby. That strange passion helped me to excel over my schooling and prepared a great platform for my career path later. I first started learning English when I was a third grader in primary school. I can still picture my first English teacher vividly in my mind now. What a caring and gentle teacher she was. At that time, I was amazed by the fact that there was another language other than Vietnamese. Before then, I thought everyone in the world all spoke my mother tongue. How naïve I was! However, English was not my focus until secondary school. I was selected at the $6^{\text {th }}$ grade to join English team to attend exams for excellent students. I got my first prize back then, which has driven me forward along the track up to now. During my schooling, my interests in English grew so fast that it surpassed my teachers' knowledge. They could not answer all of my queries, so I bought many books from the bookstores to study by myself. I hardly attended any extra classes, but reading books at home. The knowledge I got from different books was consolidated in my self-made handbook for my own references. I could say proudly that I am mostly self-taught.

Branch: It may come as a weird surprise to you, but I had no intention of being a teacher until the day I became one. I entered a teacher training university for the love of the language and my hopes to develop the proficiency of using English. I first started teaching several classes as my part-time job when I was a third-year student. During this trial time, I gained teaching skills and my interests in teaching began to grow gradually. Upon my graduation, I knew for sure my career choice would be teaching job. Working at university, I have had a great number of opportunities for professional development, learning from knowledgeable and experienced colleagues, unlimited access to libraries with a lot of relevant books and being offered teaching autonomy in classroom. Doing action research and frequent reflections on my own experience are two of my preferable ways to continue harnessing my knowledge and skills.

TPD Plan: I obtained my Master degree three years ago and have a plan to pursue doctorate degree soon in the next several years.

\subsection{Participant 4: Mollie}

Root: I come from a family with strong aspirations for intellectual development. I am a person who always loves exploration. In fact, that inquisitiveness and the receptiveness to knowledge has been the motivation for any of my learning for improvements as well as doing PhD studies.

Trunk: When I started secondary high school, I began studying English and developed my passion for it. My first teachers of English made strong impressions on me in so many ways: not just in terms of English knowledge but also their teaching methods which were different from teachers of other subjects: they encouraged students with generosity of compliments; they were openminded and used communicative approach to give us various practice in front of the class and in groups or pairs. Then I went to gifted high school, specialized in English. During my high school, I attended different English exams for gifted students and got some prizes.

When I entered university, I participated in extra-curricular activities related to English out of interest and also to enhance my competence such as being MC of English club and doing research in English. During the college years, I was self-disciplined and still kept quite strict schedule of everyday selfstudy individually or cooperatively with my best friend and others. I was quite active in the 
learning process, went to class to ask teachers questions and practiced English in front of the class as much as I could. I can say that most of my English competences have resulted from my own hard work of self-study which was of course significantly inspired and guided by my teachers and professors that I have met and learnt from. English has become my inspiration and passion. It changed me from a very shy, low self-esteem into a sociable, confident person. So I believed that English would become my major in the future no matter what specific kind of job I would have.

Branch: Attending international conferences is one of the most efficient ways of professional development because you can upgrade your knowledge with the top professors' talk and expand your professional network. I attended the $49^{\text {th }}$ RELC International Seminar on Critical Competences for the $21^{\text {st }}$ Century Language Classroom in Singapore as a speaker. And I benefited so much from that, from coming up with more ideas for my $\mathrm{PhD}$ thesis, to verify my professional development activities, and get to know more fellows.

At my university, luckily I had chances of learning from and then working with many qualified and enthusiastic teachers and professors who inspired me a lot in becoming a more competent and dynamic person. This continued to M.A then PhD studies. My PhD studies was a remarkably challenging and also rewarding journey of mine which can be called enlightening journey. I have learnt enormously from the professors, research participants during the investigation and also other PhD students. Then, it's all about paying forward, so now with my humble knowledge and experience, I have tried to support undergraduates, M.A and $\mathrm{PhD}$ students by reading their papers to give comments and suggestions. All in all, professional development is an ongoing journey so thinking and doing out of the box can possibly help us to have great achievements. Strong determination, self-discipline, creativity and other ample qualities with hard work are what it takes. Hope all the best for all of us who have strong willingness of improving ourselves day after day to become competent and effective teachers.

\subsection{Participant 5: Susan}

Root: I come from a typical Vietnamese family with teaching tradition. My dad is a physic teacher in a university. Since I was a little child, my dad has always appeared to be an exemplary teacher in my eyes. Besides, I prefer reading books, learning new things and sharing knowledge with other people. This made me consider teaching as a career I would like to pursuit.

Trunk: I became interested in English quite early. It was in my sixth grade when I started reading the series Harry Potter and wanted to understand the original version. Although I studied in a mathematicsspecialized class during high school, I still kept my passion for English. At that time, it was not only because I wanted to understand books, movies and TV programs in English, but also because I wanted to understand more about English speaking countries in particular and the world in general. In addition, my parents wanted me to become a teacher and go to Vinh university because it was next to my house. And I did so.

Branch: During my years in my university, I was both students of many good teachers and part-time English tutor to high school students. I was inspired by my teachers and at the same time helping high school students better their English brought joy to me. After graduation, I applied for a teaching position in my university and was accepted. I had one year teaching here. Though it was a short 
time, I taught various kinds of students from English major and non-major college students to English specialized high school students. This helped me accumulate real experience in teaching. After that, I started Masters' program in English. It was when I became more interested in researching, not only in the field of teaching methodology but also other fields of English linguistics and culture. Then, one of my teachers asked me to work at the Department of Science and Technology and I thought why not to try something different from teaching and accepted the offer. However, besides working at the office, I kept on teaching and tutoring. During my time working here, I had opportunities to participate in training workshops such as researching methodology, extensive reading, cross-cultural communication, and etc., which broadened my knowledge of researching also teaching.

TPD Plan: Nevertheless, now I'm still navigating. By examining my own career journey, I hope I may find out my strengths and weaknesses and what I really would like to do in the future.

\subsection{Participant 6: Cathie}

Root: I come from a small village in the North of Vietnam. Like any other parents, mine always wanted me to study well at school and get a stable job when I grew up. In their opinion, teaching was the most suitable job for me, or my siblings, although none of them or my family members were teachers. Talking about myself, I have been quite extroverted and I like learning new things and gaining new experiences a lot. Naturally, I also want to be helpful and to be recognized by the community.

Trunk: I started learning English in grade 6. During my years at school, English was something interesting, new and fun. I enjoyed all the English lessons and had quite good relationships with my teachers. They often encouraged me to go to a language university. As teaching had always been the choice for me and when thinking of being trained to be an English teacher, it was the best place, so it was obvious that I applied to it without questioning.

Branch: Having said that, doing the teacher training program was really a milestone in my life. While I chose teaching as my future job, I had never seen why I loved it or how I could be a good teacher. Then in this university, I was taught by dedicated and wonderful lecturers, who were experts in their fields and always nice and inspiring to students; and I realized I just wanted to be like them. Teaching was not the only way, or the best way, but may be the most suitable way for me to be helpful and recognized. I was inspired to work hard and study hard to be able to take my own path and build my dreams. That is exactly what I want to do for other people, more specifically my students through English lessons.

From then on, I have been under long training sessions to become what I am now. Most of my skills and experiences were gained through the part-time job as a private English tutor when I was still a student, the tutoring programs and the teaching practicum period at university, the conferences on English teaching I attended after graduating, the post-graduate course in Language Teaching Methodology I took and the time I worked as an academic manager or an English trainer in different educational organizations. I also did some research on teaching different English skills such as speaking and reading, and how English can be used in the teacher's instructions during a lesson. I understand that a good teacher needs to have enough patience and knowledge of the field, as well 
as a professional manner and critical thinking; but most importantly, a good teacher needs to be open-mined, tolerant and willing to learn and share.

TPD Plan: Working now with fantastic colleagues is my excellent opportunity to improve myself. There are a lot of things for me to learn, but I will initially focus on Teaching Methodology and then Testing and Assessment. I believe it's always important to study new methods of teaching because language is always changing and different target learners will require a specific approach to get motivated. Moreover, Testing and Assessment is an essential part of teaching job, which I think all teachers should have full knowledge of and necessary skills in. In the future, I will continue to do more research on these fields, attend more conferences with experts from different countries and maybe sign up for some courses to keep myself active, open and exposed to the latest information of the world.

\subsection{Participant 7: Liam}

Root: Regarding the root of the tree, I would like to acknowledge that my family background plays an important role in shaping my career choice. Both my parents are literature teacher, and over the years, they have tried to pass down their love of teaching to me. At first, I did not really picture myself in the future as a teacher, yet I have realized that when I do not teach, I miss the feeling of being in class with students.

Trunk: I learned English quite earlier, perhaps when I was in grade three, but it was not my favorite subject. It was not until my first encounter with a native speaker perhaps when I was in grade five. Realizing that English was a practical subject, I became more interested in it. Despite my effort, I was still not one of the best students in my class.
During my secondary school life, I had more opportunities to use English with international students studying at an international institution next to my school. (Thanks to my teacher who frequently organized visiting trips which allowed us to mingle with those kids and learn from native English speaking teachers.) My English at that time was still quite rudimentary though. During the three years at high school, I managed to significantly improve my English (especially grammar and vocabulary), but I had no opportunity to practice English communicatively. I decided to enroll in an English language teacher training program firstly because of its tuitionfree policy and secondly due to a naïve belief that I could spend the next four years just on learning English.

Branch: Finally, I will reflect on the limb of my tree of life. During my undergraduate study, at first, my listening skills were very rudimentary. Thanks to a teacher who gave me a gift during a listening activity, I had the motivation to keep trying and improving. One activity I did every night at that time was to listen to VOV5 radio program before going to bed. As a results, my listening skills improved dramatically. I started tutoring in my second year at college, but I only earned money from teaching after graduation. In my first few years of teaching, I was assigned to teach English to ethnic students. (Many of them were struggling to learn English as a third language.) Thanks to that experience, I have learnt to be patient with my students and enjoyed working together in a small and cozy community of practice.

In addition to my full time job, I decided to accept part-time tutoring work from various institutions and schools at different levels (both university and high school) to enrich my teaching experience. In 2007, I got some scholarships to pursue postgraduate education 
in Australia. During that time, I had chances to study with experts in the field and immerse myself in a true academic environment. I learnt more about teaching methodology, second language acquisition, computer assisted language learning, intercultural communication, and doing research. Most importantly, I learnt to embrace a life-long learning attitude.

TPD Plan: Reflecting on my tree of life, I have realized that recently I have neglected collaborating with my colleagues, as I spent most of my time on private tutoring jobs. Perhaps a suitable professional development activity for me now is to set up or join a group of colleagues who are willing to share time reflecting on their daily practice, conducting team teaching and classroom observation, and perhaps even doing research together.

\section{Conclusion}

This paper has provided eight narratives told by the participants using the tool Tree of life to reflect on the root, trunk, and branches of their teaching history and often concludes with the teacher's plan to move forward in their teaching career. The stories presented illustrate how narrative inquiry can be used for encouraging teachers to take the initiative in their own professional development. As mentioned before, this paper does not offer any analysis of these stories but will present them in another follow up article. It is also hoped that these stories will stimulate the readers to reflect on their own teaching careers or life history in order to actively become the architect of their own life-long professional development.

Self-reflection for language teachers as exemplified in this paper is a self-initiated, self-directed, and self-evaluated process which allows teachers to reflect on how they got where they are today, how they conduct practice, and their underlying assumptions, values and beliefs that have guided their past and current practices. Once having known themselves better and really appreciated how much they have accomplished and grown during their careers, teachers can make appropriate plans for future professional. After reading and reflecting on the teachers' journey shared in this paper, readers are encouraged to use the tool Tree of life to 'tell' their own story. The next step would be to share these stories with other teachers. By sharing with a critical friend, teachers may have different insights into the meaning and interpretation of the stories than if they are to be analyzed alone. Meanwhile, school managers and teacher educators should aim to foster a learning community where teachers can freely share with each other about their practices and concerns without any fear of being judged. Yet, that would be presented in another article.

\section{References}

Barkhuizen, G. (2008). A narrative approach to exploring context in language teaching. ELT Journal, 62(3), 231-239.

Bell, J. S. (2002). Narrative inquiry: More than just telling stories. TESOL Quarterly, 36(2), 207-213.

Bruner, J. (1986). Actual minds, possible worlds. Cambridge, MA: Harvard University Press.

Clandinin, D. J., \& Connelly, F. M. (2000). Narrative inquiry: Experience and story in qualitative research. San Francisco, CA: Jossey-Bass Inc.

Connelly, F. M., \& Clandinin, D. J. (1986). On narrative method, personal philosophy, and narrative unities in the story of teaching. Journal of Research in Science Teaching, 23(4), 293-310.

Connelly, F. M., \& Clandinin, D. J. (2006). Narrative inquiry. In J. L. Green, G. Camilli, \& P. B. Elmore (Eds.), Handbook of complementary methods in education research (pp. 447-488). Mahwah, NJ: Lawrence Erlbaum.

Cortazzi, M. (1993). Narrative analysis. London: The Falmer Press.

Dewey, J. (1938). Experience and education. New York: 
Macmillan.

Dewey, J. (1991). How we think. Buffalo, NY: Prometheus Books.

Farrell, T. S. C. (2007). Reflective language teaching: From research to practice. New York, London: Continuum.

Hardy, I. J. (2012). The politics of teacher professional development: Policy, research and practice. New York: Routledge.

Johnson, K. E., \& Golombek, P. R. (2002). Teachers' narrative inquiry as professional development. Cambridge: Cambridge University Press.

Lange, D. (1990). A blueprint for a teacher development program. In J. C. Richards \& D. Nunan (Eds.), Second language teacher education (pp. 245-268). New York: Cambridge University Press.
Mann, S. (2005). The language teacher's development. Language Teaching, 38, 103-118.

Merryfield, M. (1993). Reflective practice in global education: Strategies for teacher educators. Theory into practice, 32(1), 27-32.

Murray, A. (2010). Empowering teachers through professional development. English Teaching Forum, 1(1), 2-11.

Ncube, N. (2006). The tree of life project: using narrative ideas in work with vulnerable children in Southern Africa. International Journal of Narrative Therapy \& Community Work, 2006(1), 3-16.

Wallace, M. J. (1991). Training foreign language teachers: A reflective approach. Cambridge: Cambridge University Press.

White, M. \& Epston, D. (1990). Narrative means to therapeutic ends. New York: Norton.

\title{
CÂY CUỘC ĐỜI: GIÁO VIÊN TIẾNG ANH CHIÊM NGHIỆM VỀ QUÁ TRİNH GIẢNG DẠY
}

\author{
Mai Ngọc Khôi \\ Khoa Su phạm tiếng Anh, Trường Đại học Ngoại ngũ, ĐHQGHN, \\ Phạm Văn Đồng, Cầu Giấy, Hà Nội, Việt Nam
}

Tóm tắt: Bài viết là một minh chứng về nỗ lực sử dụng nghiên cứu tường thuật trong nghiên cứu về giáo dục, nhấn mạnh tầm quan trọng của việc tạo cơ hội cho giáo viên chiêm nghiệm và chia sẻ với đồng nghiệp. Bài báo trình bày các câu chuyện được thu thập sau giai đoạn đầu: thu thập dữ liệu bằng cách sử dụng công cụ 'Cây cuộc đời’ để tạo cơ hội cho giáo viên chiêm nghiệm về sự nghiệp và quá trình giảng dạy của họ như một hoạt động phát triển chuyên môn. Bằng cách kể câu chuyện của họ, giáo viên có thể hiểu rõ hơn về bản thân, trân trọng hơn những gì đã đạt được và quá trình trưởng thành về chuyên môn, từ đó có thể đưa ra kế hoạch phù hợp và có ý nghĩa cho sự phát triển nghề nghiệp trong tương lai.

Tì khóa: nghiên cứu tường thuật, chiêm nghiệm, cây cuộc đời, phát triển chuyên môn 